\title{
Warunki przepływu pomocy publicznej do podmiotów gospodarczych w ujęciu polskiego prawodawstwa
}

\section{Conditions of Flow of Public Aid to Economic Agents in Terms of Polish Legislation}

Streszczenie: Istnieje szereg regulacji, które odnoszą się do przepływu pomocy publicznej do podmiotów gospodarczych. W szczególności warunki przepływu tej pomocy zostały wkomponowane w nową Ustawę z dnia 15 maja 2015 r. Prawo restrukturyzacyjne (Dz.U. z 2015 r., poz. 978 z późn. zm.), która poświęca pomocy publicznej 10 artykułów (art. 140-art. 149). Artykuły te tworzą, we wspomnianej wyżej ustawie, odrębny dział I (w ramach tytułu I), zatytułowany Pomoc publiczna. Bardziej szczegółowo problem pomocy publicznej został uregulowany przez polskiego prawodawcę w Ustawie $z$ dnia 30 kwietnia 2004 r. o postępowaniu w sprawach dotyczacych pomocy publicznej (tekst jednolity: Dz.U. z 2007 r. Nr 59, poz. 404 z późn. zm.). Przepływ pomocy publicznej odbywa się na podstawie specyficznej konstrukcji prawnej, która składa się z wielu - skorelowanych ze sobą - elementów. Analiza zawarta $\mathrm{w}$ niniejszym artykule jest ukierunkowana na przedstawienie tej wieloelementowej struktury normatywnej, z uwzględnieniem prawa Unii Europejskiej.

\begin{abstract}
There is a number of regulations which refer to the flow of public aid to economic agents. In particular, the conditions of flow of this aid have been introduced in the new statute of 15th May 2015 Restructuring Law (Journal of Laws of 2015, item 978 with later amendments), which dedicate ten articles to public aid (article 140 - article 149). These articles form, in the above-mentioned statute, a separate section I (in a framework of title I) entitled Public aid. In more detail, the problem of the public aid has been regulated by the Polish legislator in the statute of 30th April 2004 on proceedings in the matters concerning the public aid (consolidated text: Journal of Laws of 2007, No. 59, item 404 with later amendments). The flow of public aid is realized on the ground of a specific legal construction, which consists of a large number of elements correlated with each other. Analysis included in this article is directed on presenting this multi-element structure, with regard to the European Union law.
\end{abstract}

Słowa kluczowe: podmiot gospodarczy; pomoc publiczna; polskie prawodawstwo

Key words: economic agent; Polish legislation; public aid

Otrzymano: 29 lutego 2016

Received: 29 February 2016

Zaakceptowano: 15 maja 2016

Accepted: 15 May 2016

\section{Sugerowana cytacja/Suggested citation:}

Woroniecki, P.M. (2016). Warunki przepływu pomocy publicznej do podmiotów gospodarczych w ujęciu polskiego prawodawstwa. Przedsiębiorczość - Edukacja, 12, 190-198. 
Wstęp

Możliwość przepływu strumienia pomocy publicznej do podmiotów gospodarczych została przez polskiego prawodawcę szczegółowo unormowana, czego przykładem są chociażby przepisy Ustawy z dnia 30 kwietnia 2004 r. o postępowaniu w sprawach dotyczacych pomocy publicznej (tekst jednolity: Dz.U. z 2007 r. nr 59, poz. 404 z późn. zm.). Ustawa ta beneficjentem pomocy nazywa podmiot zajmujący się prowadzeniem działalności gospodarczej, także tej z zakresu rolnictwa bądź rybołówstwa, niezależnie od formy organizacyjno-prawnej oraz sposobu finansowania, jednocześnie spełniający warunek polegający na otrzymaniu pomocy publicznej (art. 2 pkt 16 wspomnianej wyżej ustawy). Dalsze dociekania zmierzają do ukazania przyjętej przez polskiego prawodawcę konstrukcji prawnej, na której opiera się system przepływu pomocy publicznej. W ten sposób ujęty cel badawczy wymaga szczegółowego przyjrzenia się elementom składającym się na tę konstrukcję prawną.

Mając na uwadze dalsze rozważania, warto przytoczyć treść artykułu 2 pkt 6 Ustawy o postępowaniu w sprawach dotyczacych pomocy publicznej, który przewiduje, że w każdym przypadku, gdy ustawa ta posługuje się pojęciem ,pomoc indywidualna na restrukturyzację - należy przez to rozumieć pomoc indywidualną przewidzianą w planie restrukturyzacyjnym określającym działania mające na celu przywrócenie przedsiębiorcy długookresowej zdolności do konkurowania na rynku, w szczególności sposób finansowania tych działań, w tym również przez udzielanie pomocy publicznej".

\section{Zmiany strukturalne a przepływ pomocy publicznej z perspektywy polskich przepisów prawnych}

W kontekście treści wspomnianego wyżej art. 2 pkt 6 Ustawy o postępowaniu $w$ sprawach dotyczących pomocy publicznej, trzeba zwrócić uwagę na zamieszczony w Ustawie $z$ dnia 15 maja 2015 r. Prawo restrukturyzacyjne (Dz.U. z 2015 r., poz. 978 z późn. zm.) dział V zatytułowany Pomoc publiczna (art. 140-art. 149) usytuowany w obrębie tytułu I pod tytułem Przepisy ogólne o postępowaniach restrukturyzacyjnych $i$ ich skutkach. Otóż art. 142 ust. 1 pkt 1 ustawy Prawo restrukturyzacyjne przewiduje, że można udzielić pomocy publicznej na restrukturyzację po to, by zrealizować plan restrukturyzacyjny umożliwiający przedsiębiorcy powrót do sytuacji, w której będzie miał on zdolność do uczestnictwa w konkurencji rynkowej, przy czym zdolność ta ma polegać na możliwości pokrywania kosztów związanych z działalnością gospodarczą, wliczając w to koszty amortyzacji i koszty finansowe. Ponadto, zgodnie z art. 142 ust. 1 pkt 2 ustawy Prawo restrukturyzacyjne, istnieje możliwość udzielenia pomocy publicznej na restrukturyzację w sytuacji, gdy metoda restrukturyzacji jest właściwa do tego, by usunąć przyczyny powodujące trudną sytuację ekonomiczną przedsiębiorcy. I wreszcie, w art. 142 ust. 1 pkt 3 ustawy Prawo restrukturyzacyjne, prawodawca postanowił o dopuszczalności pomocy publicznej na restrukturyzację, o ile chroni ona przed trudnościami społecznymi lub powoduje przezwyciężenie niedoskonałości cechujących rynek, a jednocześnie gdyby tej pomocy nie było, to nie doszłoby do osiągnięcia rzeczonego celu bądź zostałby on osiągnięty, ale w mniejszym stopniu.

Trzeba w tym miejscu podkreślić, że - w myśl art. 144 ust. 1 pkt 1, pkt 2, pkt 3 ustawy Prawo restrukturyzacyjne - pomoc publiczna służąca restrukturyzacji może być tylko uzupełnieniem środków własnych danego przedsiębiorcy, środków wyasygnowanych przez tych, którzy 
są akcjonariuszami lub udziałowcami przedsiębiorcy, lub przez innych przedsiębiorców objętych tą samą grupą kapitałową co ten przedsiębiorca, przez wierzycieli przedsiębiorcy, przy czym w każdej z wyżej wymienionych sytuacji chodzi o uzupełnienie w zakresie koniecznym do urzeczywistnienia celu wskazanego w art. 142 ust. 1 pkt 1 ustawy Prawo restrukturyzacyjne.

Należy jednak pamiętać o zakazie udzielania pomocy publicznej na restrukturyzację w przypadku, gdy środki restrukturyzacyjne ustanowione planem restrukturyzacyjnym sprowadzają się jedynie do zrestrukturyzowania zobowiązań (art. 142 ust. 3 pkt 1 ustawy Prawo restrukturyzacyjne). Co więcej, ustawodawca nie pozwala udzielać pomocy publicznej na restrukturyzację, o ile wynikające z planu restrukturyzacyjnego środki restrukturyzacyjne zawierają założenie dotyczące nowych inwestycji, z wyłączeniem inwestycji koniecznych do tego, by przedsiębiorca odzyskał długookresową zdolność do uczestniczenia w rynkowej konkurencji (art. 142 ust. 3 pkt 2 ustawy Prawo restrukturyzacyjne).

Z drugiej strony art. 143 ust. 1 pkt 1 i pkt 2 lit. a, lit. b, lit. c ustawy Prawo restrukturyzacyjne wskazuje, że wolno udzielić pomocy publicznej na zrestrukturyzowanie, gdy chodzi o przedsiębiorcę, który nie uzyskał uprzednio następującej pomocy publicznej: dla ratowania, tymczasowej na rzecz restrukturyzacji lub niemającej charakteru tymczasowego służącej restrukturyzacji, albo uzyskał którąkolwiek pomoc spośród powyższych i upłynął okres minimum 10 lat liczony od dnia zajścia najpóźniejszej z okoliczności polegających na: a) przyznaniu pomocy publicznej dla przedsiębiorcy, b) zakończeniu wykonywania uprzedniego planu restrukturyzacyjnego bądź c) zaprzestaniu wykonywania tegoż planu. Warto jednak nadmienić, że art. 143 ust. 2 ustawy Prawo restrukturyzacyjne dopuszcza możliwość udzielania pomocy publicznej na restrukturyzację zanim jeszcze upłynie dziesięcioletni okres od dnia, w którym została przyznana przedsiębiorcy pomoc publiczna dla ratowania lub tymczasowa pomoc publiczna służąca restrukturyzacji, $\mathrm{z}$ tym że musi zaistnieć sytuacja wskazana w pkt 1 albo w pkt 2 , albo w pkt 3 ustępu 2 artykułu 143 rzeczonej ustawy.

Ustawodawca wprowadza zastrzeżenie, że można udzielić pomocy publicznej na restrukturyzację, o ile przedsiębiorca podejmie środki, których celem jest wyrównanie zakłóceń konkurencji w obrębie rynku (art. 145 ust. 1 ustawy Prawo restrukturyzacyjne). Środki służące wyrównaniu zakłóceń konkurencji w obszarze rynku to środki strukturalne, środki behawioralne oraz środki określane mianem ,otwarcia rynku” (art. 145 ust. 2 pkt 1, pkt 2, pkt 3 ustawy Prawo restrukturyzacyjne). Środkami strukturalnymi są takie środki, które sprowadzają się zwłaszcza do tego, że zbyciu ulegają aktywa (w miarę możliwości występujące jako zorganizowana część przedsiębiorstwa), ograniczane są zdolności produkcyjne, ograniczany jest udział, jaki przedsiębiorca posiada na rynku (art. 145 ust. 3 pkt 1, pkt 2, pkt 3 ustawy Prawo restrukturyzacyjne). $\mathrm{Z}$ kolei w art. 145 ust. 4 ustawy Prawo restrukturyzacyjne ustawodawca wskazał w trzech kolejnych punktach, w czym w szczególności znajdują wyraz środki behawioralne. Mianowicie, zgodnie $\mathrm{z}$ art. 145 ust. 4 pkt 1 i pkt 2 rzeczonej ustawy, sprowadzają się one do tego, że nie są nabywane akcje lub udziały podczas procesu restrukturyzacyjnego i wypełniania układu (z wyłączeniem sytuacji, gdy trzeba to zrobić dla urzeczywistnienia celu przewidzianego artykułem 142 ust. 1 pkt 1 ustawy Prawo restrukturyzacyjne) oraz do tego, że nie są rozpowszechniane informacje mówiące o przewadze konkurencyjnej produktów lub usług przedsiębiorcy nad pozostałymi produktami tudzież usługami z uwagi na fakt udzielenia pomocy publicznej służącej restrukturyzacji. Natomiast art. 145 ust. 4 pkt 3 ustawy Prawo restrukturyzacyjne stanowi, że środkiem behawioralnym jest brak podejmowania działań ukierunkowanych na to, by zdobyć nowe rynki. I wreszcie, zgodnie z art. 145 ust. 5 ustawy Prawo restrukturyzacyjne, mówiąc o środkach otwarcia rynku ustawodawca ma na myśli te środki, które sprowadzają się zwłaszcza do tego, że stanowią dla innych przedsiębiorców ułatwienie w wejściu na rynek. 
Warto zwrócić uwagę na szczegółowe rozwiązania zawarte zwłaszcza w art. 143 ust. 3 i ust. 4 ustawy Prawo restrukturyzacyjne. Otóż zgodnie z art. 143 ust. 3 rzeczonej ustawy, przedsiębiorca wchodzący w skład grupy kapitałowej może dostać pomoc publiczną na restrukturyzację w sytuacji, gdy jakikolwiek przedsiębiorca będący członkiem wspomnianej grupy kapitałowej uzyskał pomoc w formie pomocy publicznej dla ratowania, tymczasowej pomocy publicznej na rzecz restrukturyzacji lub pomocy publicznej służącej restrukturyzacji, o ile minął już dziesięcioletni okres czasu liczony od dnia zaistnienia najpóźniejszego z określonych zdarzeń. Jak wskazuje rzeczony art. 143 ust. 3 ustawy Prawo restrukturyzacyjne, tymi zdarzeniami są udzielenie wspomnianej wyżej pomocy lub zakończenie albo zaprzestanie wykonywania uprzedniego planu restrukturyzacyjnego jakiegokolwiek przedsiębiorcy funkcjonującego w ramach tejże grupy kapitałowej.

Natomiast art. 143 ust. 4 ustawy Prawo restrukturyzacyjne stanowi, że w sytuacji, gdy doszło do otrzymania przez przedsiębiorcę uczestniczącego w grupie kapitałowej pomocy publicznej służącej ratowaniu, tymczasowej pomocy publicznej dla restrukturyzacji lub pomocy publicznej na rzecz restrukturyzacji, innemu przedsiębiorcy funkcjonującemu w ramach tej grupy można dać pomoc publiczną na rzecz restrukturyzacji zanim upłynie wspomniany wyżej dziesięcioletni okres liczony w stosunku do przedsiębiorcy będącego w tej samej grupie, i na rzecz którego zadysponowano już pomocą publiczną, jednakże jest to możliwe pod pewnym warunkiem. Jak stanowi analizowany art. 143 ust. 4 ustawy Prawo restrukturyzacyjne, warunek ten wyraża się w tym, iż zaplanowana pomoc publiczna na rzecz restrukturyzacji nie zostanie wyasygnowana na rzecz tego ostatniego przedsiębiorcy.

W dalszej kolejności ustawodawca postanawia w art. 143 ust. 5 ustawy Prawo restrukturyzacyjne, że można udzielić pomocy publicznej przedsiębiorcy będącemu nabywcą aktywów od zbywcy, którym jest inny przedsiębiorca cechujący się tym, że dostał on już pomoc w postaci pomocy publicznej dla ratowania, tymczasowej pomocy publicznej służącej restrukturyzacji lub pomocy publicznej na rzecz restrukturyzacji przed zbyciem tychże aktywów, o ile upłynął już wystarczająco długi okres czasu wynoszący nie mniej niż 10 lat, począwszy od dnia, w którym miało miejsce najpóźniejsze z konkretnych zdarzeń. Ten sam art. 143 ust. 5 ustawy Prawo restrukturyzacyjne wyjaśnia, że takowymi zdarzeniami jest udzielenie wspomnianej wyżej pomocy lub zakończenie albo zaprzestanie realizacji wcześniejszego planu restrukturyzacyjnego zbywcy aktów, którym jest przedsiębiorca.

Zgodnie z art. 143 ust. 6 ustawy Prawo restrukturyzacyjne istnieje możliwość udzielenia pomocy publicznej na restrukturyzację przedsiębiorcy o statusie nabywcy aktywów od zbywcy będącego innym przedsiębiorcą, który dostał pomoc w formie pomocy publicznej dla ratowania, tymczasowej pomocy publicznej służącej restrukturyzacji lub pomocy publicznej na rzecz restrukturyzacji przed zbyciem rzeczonych aktywów zanim jeszcze upłynie wspomniany wyżej okres 10 lat, o ile jednak po stronie nabywcy tychże aktywów nie ma kontynuacji działalności gospodarczej wykonywanej przez przedsiębiorcę, który dostał pomoc.

\section{Dalsze regulacje związane z pomocą publiczną}

Zaznaczyć należy, że Ustawa o postępowaniu w sprawach dotyczących pomocy publicznej określa reguły, jakie znajdują zastosowanie w kwestiach pozostających w związku z pomocą państwa spełniającą przesłanki przewidziane artykułem 87 ust. 1 Traktatu ustanawiającego Wspólnotę Europejską (która to pomoc określana jest w rzeczonej ustawie mianem pomocy publicznej), ,,w tym: 1) postępowanie w sprawie przygotowania do notyfikacji projektów 
programów pomocowych, projektów pomocy indywidualnej oraz projektów pomocy indywidualnej na restrukturyzację" (art. 1 pkt 1 Ustawy o postępowaniu w sprawach dotyczących pomocy publicznej). W kolejnych punktach tegoż art. 1 Ustawy o postępowaniu w sprawach dotyczacych pomocy publicznej, tj. w pkt 2, pkt 3, pkt 4 i pkt 5, ustawodawca wylicza dalsze kwestie regulowane wspomnianą wyżej ustawą, które wpisują się we wspomniane wyżej reguły, przy czym całe to wyliczenie, włącznie ze wspomnianym pkt 1, otwiera zwrot „,w tym”, co świadczy o niewyczerpującym charakterze tego wyliczenia.

W związku z zamieszczonym w przytoczonym wyżej art. 1 Ustawy o postępowaniu w sprawach dotyczacych pomocy publicznej odwołaniem do art. 87 ust. 1 Traktatu ustanawiającego Wspólnotę Europejską oraz mając na uwadze doniosłe znaczenie tego przepisu traktatowego, trzeba pokrótce wyjaśnić pewne - dość złożone zresztą - kwestie związane z tą regulacją.

Zaczynając od sprawy samego tytułu wspomnianego wyżej Traktatu ustanawiającego Wspólnotę Europejską, należy przypomnieć, że to Traktat o Unii Europejskiej sporządzony w Maastricht 7 lutego 1992 r. (Dz.U. z 2004 r. nr 90, poz. 864, załącznik nr 2, tom II, s. 492) w jej pierwotnej wersji stanowił w artykule G lit. A pkt 1, że:

„W celu ustanowienia Wspólnoty Europejskiej w Traktacie ustanawiajacym Europejska Wspólnotę Gospodarcza wprowadza się zmiany zgodnie z postanowieniami niniejszego artykułu.

A. - W całym Traktacie:

1) Termin »Europejska Wspólnota Gospodarcza« zastępuje się terminem »Wspólnota Europejska»".

Natomiast w kwestii wspomnianego wyżej numeru artykułu traktatowego (art. 87) trzeba nadmienić, że Traktat $z$ Amsterdamu zmieniający Traktat o Unii Europejskiej, Traktaty ustanawiajace Wspólnoty Europejskie i niektóre związane z nimi akty sporządzony w Amsterdamie 2 października 1997 r. (Dz.U. z 2004 r. nr 90, poz. 864, załącznik nr 2, tom II, s. 553) wprowadził w swoim art. 12 zapis, w myśl którego: „Artykuły, tytuły i sekcje Traktatu o Unii Europejskiej i Traktatu ustanawiającego Wspólnotę Europejską, zmienione postanowieniami niniejszego Traktatu, otrzymują zmienioną numerację, zgodnie z tabelą ekwiwalencyjną zamieszczoną w Załączniku do niniejszego Traktatu, stanowiącym jego integralną część”. I tak, zgodnie z tym Załącznikiem zatytułowanym Tabela ekwiwalencyjna, o której mowa w art. 12 Traktatu z Amsterdamu, numer 87 został nadany temu artykułowi w miejsce poprzedniego numeru 92. Poza nadaniem nowego numeru 87, Traktat $z$ Amsterdamu wprowadził też pewne zmiany do tegoż artykułu Traktatu ustanawiającego Wspólnotę Europejska, przy czym nie dotyczyły one ustępu 1 tegoż artykułu (zob. umieszczony w Traktacie z Amsterdamu art. 6 ust. I zatytułowany Tekst artykułów Traktatu pkt 51). Jednocześnie do Traktatu z Amsterdamu został załączony w szczególności tekst Traktatu ustanawiającego Wspólnotę Europejską, uwzględniający m.in. zmienioną numerację artykułów, z którego to tekstu wynika, następujące brzmienie art. 87 ust. 1 Traktatu ustanawiającego Wspólnotę Europejską: „Z zastrzeżeniem innych postanowień przewidzianych w niniejszym Traktacie, wszelka pomoc przyznawana przez Państwo Członkowskie lub przy użyciu zasobów państwowych w jakiejkolwiek formie, która zakłóca lub grozi zakłóceniem konkurencji poprzez sprzyjanie niektórym przedsiębiorstwom lub produkcji niektórych towarów, jest niezgodna ze wspólnym rynkiem w zakresie, w jakim wpływa na wymianę handlową między Państwami Członkowskimi”.

To jednak jeszcze nie koniec, bowiem Traktat z Lizbony zmieniajacy Traktat o Unii Europejskiej i Traktat ustanawiający Wspólnotę Europejska, sporządzony w Lizbonie dnia 13 grudnia 2007 r. (Dz.U. z 2009 r. nr 203, poz. 1569) zawiera w art. 2 pkt 1 następujące postanowienie: 
„Traktat ustanawiający Wspólnotę Europejską zmienia się zgodnie z postanowieniami niniejszego artykułu.

1) Nagłówek Traktatu otrzymuje brzmienie: »Traktat o funkcjonowaniu Unii Europejskiej«".

Natomiast, analogicznie jak art. 12 Traktatu z Amsterdamu, art. 5 rzeczonego Traktatu $z$ Lizbony stanowi: „Artykuły, sekcje, rozdziały, tytuły i części Traktatu o Unii Europejskiej i Traktatu ustanawiającego Wspólnotę Europejską, zmienione niniejszym Traktatem, otrzymują nowe oznaczenia zgodnie z tabelami ekwiwalencyjnymi zamieszczonymi w załączniku do niniejszego Traktatu, który stanowi jego integralną częśćc. Zgodnie ze wspomnianym załącznikiem (zatytułowanym Tabele ekwiwalencyjne, o których mowa $w$ artykule 5 Traktatu zmieniającego Traktat o Unii Europejskiej i Traktat ustanawiający Wspólnotę Europejska) do Traktatu z Lizbony, artykuł 87 Traktatu ustanawiającego Wspólnotę Europejską otrzymał inny numer i jest to obecnie art. 107 Traktatu o funkcjonowaniu Unii Europejskiej. Oprócz zmiany numeru artykułu 87 na 107, Traktat $z$ Lizbony wprowadził też pewne drobne modyfikacje w treści ust. 1 tego artykułu. Pierwsza modyfikacja związana jest $\mathrm{z}$ wymogiem zastąpienia w ramach całego Traktatu (chodzi o Traktat o funkcjonowaniu Unii Europejskiej) zwrotu „»w niniejszym traktacie«" słowami „»W Traktatach «" (zob. art. 2 pkt 2 lit b Traktatu z Lizbony). Natomiast druga zmiana wynika z konieczności uwzględnienia art. 2 pkt 2 lit. g Traktatu z Lizbony, który to przepis przewiduje wprowadzenie następującej modyfikacji w ramach całego Traktatu (chodzi o Traktat o funkcjonowaniu Unii Europejskiej): ,,wszystkie formy gramatyczne wyrazów »wspólny rynek« zastępuje się odpowiednią formą gramatyczną wyrazów »rynek wewnętrzny«, natomiast występujące przed nimi przyimki »ze« lub »we« zastępuje się, odpowiednio, przyimkami »Z« lub »W«".

Trzeba jeszcze zaznaczyć, że Traktat ofunkcjonowaniu Unii Europejskiej (opublikowany pod pierwotnym tytułem Traktat ustanawiający Europejską Wspólnotę Gospodarczą w: Dz.U. z 2004 r. nr 90, poz. 864, załącznik nr 2, tom I, s. 10 z późn. zm.) stanowi w art. 26 ust. 2, iż rynkiem wewnętrznym objęty jest obszar pozbawiony granic wewnętrznych i cechujący się tym, że w jego ramach zapewniony jest swobodny przepływ, któremu podlegają towary, osoby, usługi i kapitał, stosownie do postanowień traktatów.

W piśmiennictwie podkreśla się, że konieczność objęcia - w państwach należących do Unii Europejskiej - regulacją prawną zarówno warunków, na jakich udzielana jest pomoc publiczna, jak i nadzoru nad tą pomocą wynika $\mathrm{z}$ faktu, że pomoc publiczna wpływa w istotny sposób na zjawiska ekonomiczne, co w powiązaniu ze swobodą organów państwa w zakresie dysponowania środkami publicznymi może skutkować zakłóceniem mechanizmów, którymi rządzi się gospodarka rynkowa oraz zniekształceniem konkurencji, jaka występuje między przedsiębiorstwami (Germann, Ušák, 2007).

Należy zwrócić uwagę na rozdział 6 zatytułowany Monitorowanie pomocy publicznej (art. 31-art. 41) umiejscowiony w Ustawie o postępowaniu w sprawach dotyczacych pomocy publicznej. Artykuł 31 ust. 1 tej ustawy stanowi: „Monitorowanie pomocy publicznej obejmuje gromadzenie, przetwarzanie i przekazywanie informacji o udzielanej pomocy publicznej, w szczególności o jej rodzajach, formach i wielkości, oraz przestrzeganie krajowego limitu skumulowanej kwoty pomocy de minimis w rolnictwie lub rybołówstwie". W ust. 2 tego samego art. 31 ustawodawca zadecydował, że to Prezes Urzędu jest tym organem, który monitoruje pomoc publiczną, przy czym jeżeli chodzi o pomoc publiczną związaną z rolnictwem lub rybołówstwem, to takim organem jest minister właściwy w sprawach rolnictwa. Należy nadmienić, że - jak o tym stanowi art. 1 pkt 2 Ustawy o postępowaniu w sprawach dotyczacych pomocy publicznej - stosowane w tej ustawie pojęcie „Prezes Urzędu” oznacza Prezesa Urzędu 
Ochrony Konkurencji i Konsumentów. W literaturze wskazuje się, że dla monitorowania pomocy publicznej fundamentalne znaczenie ma po pierwsze wymóg polegający na składaniu sprawozdań, a po drugie możność dokonywania kontroli (Kwapisz-Krygel, 2015).

W myśl art. 32 ust. 1 Ustawy o postępowaniu w sprawach dotyczących pomocy publicz$n e j$, na podmiotach udzielających pomocy ciąży obowiązek wyrażający się w sporządzeniu i przedstawieniu Prezesowi Urzędu określonych danych, to jest sprawozdań na temat pomocy publicznej, której udzielono (oprócz pomocy niebędącej pomocą publiczną w obszarze rolnictwa lub rybołówstwa) albo informacji, że taka pomoc nie została udzielona w czasie, którego dotyczy dany okres sprawozdawczy, przy czym we wspomnianych wyżej sprawozdaniach należy wskazać zwłaszcza beneficjentów pomocy, jak też rodzaje, formy, wielkość i przeznaczenie pomocy, której udzielono. Natomiast stosownie do art. 32a ust. 1 wspomnianej wyżej ustawy, podmioty zajmujące się udzielaniem pomocy są zobligowane sporządzić i przedstawić ministrowi właściwemu w sprawach rolnictwa sprawozdania obejmujące udzieloną pomoc publiczną w obszarze rolnictwa lub rybołówstwa albo informacje na temat braku udzielenia tejże pomocy w czasie obejmującym okres sprawozdawczy, z tym że ustawodawca wymaga, by sprawozdania zawierały zwłaszcza wiadomości określające beneficjentów pomocy, a także rodzaje, formy, wielkość i przeznaczenie pomocy, której udzielono.

Trzeba nadmienić, że podczas kontroli, jakiej podlega beneficjent pomocy, możliwa jest obecność osób, które upoważnił do tego Prezes Urzędu, a gdy chodzi o pomoc publiczną w obszarze rolnictwa lub rybołówstwa, to wydanie odpowiedniego upoważnienia leży w kompetencjach ministra właściwego w sprawach rolnictwa (art. 42 ust. 2 Ustawy o postępowaniu w sprawach dotyczacych pomocy publicznej).

Na zakończenie warto odwołać się do przykładu, obrazującego możliwości stosowania pomocy publicznej. Tym przykładem może być Rozporzadzenie Ministra Gospodarki z dnia 3 lutego 2009 r. w sprawie udzielania pomocy publicznej na inwestycje w zakresie budowy lub rozbudowy jednostek wytwarzajacych energię elektryczna lub ciepło z odnawialnych źródeł energii (Dz.U. z 2009 r. nr 21, poz. 112 z późn. zm.). Na wstępie tego aktu prawnego stwierdza się, że został on wydany na podstawie regulacji zawartej w art. 21 ust. 3 Ustawy z dnia 6 grudnia 2006 r. o zasadach prowadzenia polityki rozwoju (tekst jednolity: Dz.U. z 2016 r., poz. 383). Należy przypomnieć, że zgodnie z art. 1 ust. 1 wspomnianej Ustawy o zasadach prowadzenia polityki rozwoju, zawiera ona ustalenia co do reguł, na podstawie których prowadzi się politykę rozwoju, jak również co do podmiotów prowadzących taką politykę oraz trybu, w jakim podmioty te współpracują między sobą.

Wracając do rzeczonego Rozporzadzenia Ministra Gospodarki z dnia 3 lutego 2009 r., od razu trzeba znaczyć, że zgodnie z jego paragrafem 12 akt ten obowiązywał do końca czerwca 2014 r. Mimo tego, że utracił on moc prawną, jest on doskonałym przykładem możliwości wykorzystanie pomocy publicznej do realizacji ważnych - dla społeczeństwa i gospodarki zadań. Paragraf 1 ust. 1 tego rozporządzenie stwierdzał m.in., że szczegółowo reguluje ono kwestie dotyczące przeznaczenia, warunków oraz mechanizmu przekazywania pomocy publicznej objętej działaniem 9.4 wpisanym w Program Operacyjny Infrastruktura i Środowisko 2007-2013. Pomoc taka miała być ukierunkowana m.in. na inwestycje związane $z$ budową lub rozbudową ,,jednostek wytwarzających: 1) energię elektryczną, wykorzystujących energię wiatru, wody w małych elektrowniach wodnych, w których moc zainstalowana elektryczna nie przekracza $10 \mathrm{MW}$, biogaz lub biomasę, 2) energię elektryczną ze źródeł odnawialnych w kogeneracji w układach niespełniających wymogów wysokosprawnej kogeneracji” (paragraf 1 ust. 1 pkt 1 i pkt 2 rzeczonego Rozporządzenia Ministra Gospodarki z dnia 3 lutego 2009 r.). 


\section{Uwagi końcowe}

Pomoc publiczna, jak to wynika z przeprowadzonej w niniejszym opracowaniu analizy, nie została przez polskiego prawodawcę ujęta w jednym całościowym akcie prawnym. W trakcie rozważań ukazujących konstrukcję prawną pomocy publicznej, odwołano się do dwóch ustaw, a mianowicie Ustawy z dnia 15 maja 2015 r. Prawo restrukturyzacyjne oraz Ustawy $z$ dnia 30 kwietnia 2004 r. o postępowaniu w sprawach dotyczacych pomocy publicznej, a także nawiązano do przepisów unijnych. Stosunkowo szeroko omówiono grupę przepisów zawartych w dziale V (zatytułowanym Pomoc publiczna) tytułu I ustawy Prawo restrukturyzacyjne. Jeżeli chodzi natomiast o Ustawę o postępowaniu w sprawach dotyczacych pomocy publicznej, zwrócono uwagę przede wszystkim na pewne regulacje zawarte w rozdziale 6 tej ustawy pt. Monitorowanie pomocy publicznej.

Dokonując natomiast oceny omówionych rozwiązań prawnych, należy zwrócić uwagę na kilka kluczowych kwestii. Przede wszystkim jako trafne należy ocenić rozwiązanie przyjęte w art. 144 ust. 1 ustawy Prawo restrukturyzacyjne, zgodnie z którym pomoc publiczna przydzielana na restrukturyzację może jedynie stanowić uzupełnienie dla środków płynących ze źródeł wymienionych w art. 144 ust. 1 pkt 1, pkt 2 i pkt 3 ustawy Prawo restrukturyzacyjne. Co więcej, ustawodawca ściśle precyzuje, jaki musi być minimalny udział procentowy środków pochodzących z powyższych źródeł, przy czym udział ten determinowany jest kategorią przedsiębiorcy (zob. art. 144 ust. 2 pkt 1, pkt 2 i pkt 3 ustawy Prawo restrukturyzacyjne). Zwrócenie uwagi na to ostatnie rozwiązanie, dotyczące minimalnego procentowego zaangażowania danych środków jest o tyle istotne, że doskonale wpisuje się w pewną filozofię udzielania tej pomocy. Z drugiej strony błędem byłoby zakładanie, iż przepływ pomocy publicznej w zakresie regulowanym ustawą Prawo restrukturyzacyjne jest ujmowany w sztywne, nieznające wyjątków, ramy. Otóż wystarczy spojrzeć choćby do art. 143 ust. 2 tej ustawy, który to przepis daje możliwość udzielenia pomocy publicznej na restrukturyzację przed upływem okresu sprecyzowanego w tym przepisie, jeżeli spełniony zostanie wymóg przewidziany w pkt 1 albo pkt 2 albo pkt 3 tegoż ustępu 2 artykułu 143. Dla przykładu wspomniane w art. 143 ust. 2 pkt 3 ustawy Prawo restrukturyzacyjne unormowanie pozwala na odstąpienie od rygorystycznego trzymania się tego terminu, jeżeli pomoc jest niezbędna z uwagi na okoliczności charakteryzujące się tym, że przedsiębiorca za nie nie odpowiada. Tym samym można przyjąć, że na gruncie ustawy Prawo restrukturyzacyjne przepływ pomocy publicznej cechuje pewna niezbędna, szeroko rozumiana, elastyczność.

Akty prawne i literatura

Legal acts and references

Traktat o funkcjonowaniu Unii Europejskiej (opublikowany pod pierwotnym tytułem Traktat ustanawiający Europejską Wspólnotę Gospodarczą. W: Dz.U. z 2004 r. nr 90, poz. 864, załącznik nr 2, tom I, s. $10 \mathrm{z}$ późn. $\mathrm{zm}$.).

Traktat o Unii Europejskiej, sporządzony w Maastricht 7 lutego 1992 r. (Dz.U. z 2004 r. nr 90, poz. 864, załącznik nr 2, tom II, s. 492).

Traktat $z$ Amsterdamu zmieniajacy Traktat o Unii Europejskiej, Traktaty ustanawiajace Wspólnoty Europejskie i niektóre związane z nimi akty sporządzony w Amsterdamie 2 października 1997 r. (Dz.U. z 2004 r. nr 90, poz. 864, załącznik nr 2, tom II, s. 553).

Traktat z Lizbony zmieniający Traktat o Unii Europejskiej i Traktat ustanawiajacy Wspólnotę Europejska sporządzony w Lizbonie dnia 13 grudnia 2007 r. (Dz.U. z 2009 r. nr 203, poz. 1569). 
Ustawa z dnia 30 kwietnia 2004 r. o postępowaniu w sprawach dotyczących pomocy publicznej (tekst jednolity: Dz.U. z 2007 r. nr 59, poz. 404 z późn. zm.).

Ustawa z dnia 6 grudnia 2006 r. o zasadach prowadzenia polityki rozwoju (tekst jednolity: Dz.U. z 2016 r., poz. 383).

Ustawa z dnia 15 maja 2015 r. Prawo restrukturyzacyjne (Dz.U. z 2015 r., poz. 978 z późn. zm.).

Rozporzadzenie Ministra Gospodarki $z$ dnia 3 lutego 2009 r. w sprawie udzielania pomocy publicznej na inwestycje $w$ zakresie budowy lub rozbudowy jednostek wytwarzajacych energię elektryczna lub ciepło z odnawialnych źródeł energii (Dz.U. z 2009 r. nr 21, poz. 112 z późn. zm.).

Germann, J., Ušák, M. (2007). Pomoc publiczna - nadzwyczajne postępowanie nadzorcze. Finanse Komunalne, 101(6), 5-12.

Kwapisz-Krygel, K. (2015). Postępowanie w sprawach dotyczacych pomocy publicznej. Komentarz. Wydanie 1. Warszawa: Wolters Kluwer SA.

Paweł Marek Woroniecki, doktor nauk prawnych, Uniwersytet Jagielloński, Wydział Prawa i Administracji, Katedra Polityki Gospodarczej. Jego działalność badawcza dotyczy kwestii związanych zwłaszcza $\mathrm{z}$ prawem budżetowym, pozycją przedsiębiorców w systemie prawnym oraz z funkcjami administracji publicznej.

Pawel Marek Woroniecki, PhD in legal science, the Jagiellonian University, Faculty of Law and Administration, Chair of Economic Policy. His research activity refers to issues connected with especially budget law, a position of entrepreneurs in legal system and with functions of public administration.

\section{Adres/Address:}

Uniwersytet Jagielloński w Krakowie

Wydział Prawa i Administracji

Katedra Polityki Gospodarczej

ul. Bracka 12

31-005 Kraków, Polska

e-mail: pawel.woroniecki@uj.edu.pl 